\title{
Designing Comics By Using Problem Based Learning (PBL) to Improve Student's Creative Thinking Skills
}

\author{
Enny Zarvianti ${ }^{1 *}$, Desrianti Sahida ${ }^{2}$ \\ ${ }^{1,2}$ STKIP Muhammadiyah Sungai Penuh, Indonesia \\ *e-mail: ennyzarvianti@gmail.com
}

\begin{abstract}
The designing of high school/Islamic high school physics comic teaching materials has been done to improve students' critical thinking skills in Newton's Law material. The purpose of this research is to determine to develop a physics comic for high school / Islamic high school based on problem-based learning (PBL) to improve the creative thinking skills of students at MAN Sebukar. The research method used is the research and development method, namely the 4D development method which consists of 4 phases: defining, designing, developing and disseminating. The analysis results were obtained from the development of physics comics for high school / Islamic high school which have valid (0.85), practical (94.67\%), and effective criteria for skill assessment that are judges as very good category. And the final stage after developing stage, namely the disseminating stage, researchers carried out practicality and effectiveness tests in different classes and the practicality test results were obtained in the very practical category, namely $94.33 \%$ from students' response questionnaires and effectiveness test results from the assessment of students knowledge with a percentage of completeness reaching 82.33 . \% in the very good category, the students' attitude competency reached an average score of $87.43 \%$ in the very good category, the skills competency reached an average score of $89.17 \%$ with the very good category. The designing of PBL-based high school / Islamic high school physics comics is able to improve students' creative thinking skill since it eventually gives impact on students'scores.
\end{abstract}

Keywords:

Comics, Problem Based Learning (PBL); Creative Thinking Skill (CTS); 4D Models

\begin{abstract}
ABSTRAK
Perancangan bahan ajar komik fisika SMA / MA telah dilakukan untuk meningkatkan kemampuan berpikir kritis siswa pada materi Hukum Newton. Tujuan penelitian ini adalah untuk mengetahui pengembangan komik fisika untuk sekolah menengah atas / madrasah aliyah berbasis masalah (PBL) untuk meningkatkan keterampilan berpikir kreatif siswa di
\end{abstract}


MAN Sebukar. Metode penelitian yang digunakan adalah metode penelitian dan pengembangan yaitu metode pengembangan $4 D$ yang terdiri dari 4 tahap yaitu pendefinisian, perancangan, pengembangan dan diseminasi. Hasil analisis diperoleh dari pengembangan komik fisika tingkat SMA / MA yang memiliki kriteria valid $(0,85)$, praktis (94,67\%), dan efektif yang dinilai dalam kategori sangat baik. Dan tahap terakhir setelah tahap pengembangan yaitu tahap diseminasi, peneliti melaksanakan tes kepraktisan dan keefektifan di kelas yang berbeda dan hasil tes kepraktisan diperoleh dalam kategori sangat praktis yaitu 94,33\% dari angket respon siswa dan hasil tes keefektifan dari penilaian pengetahuan siswa dengan persentase ketuntasan mencapai 82,33. \% pada kategori sangat baik, kompetensi sikap siswa mencapai skor rata-rata 87,43\% dalam kategori sangat baik, kompetensi keterampilan mencapai skor rata-rata 89,17\% dengan kategori sangat baik. Perancangan komik fisika SMA / MI berbasis PBL mampu meningkatkan kemampuan berpikir kreatif siswa karena pada akhirnya berdampak pada nilai siswa.

\section{Kata kunci:}

Komik; PBL; Kemampuan Berfikir Kreatif; Model Pengembangan 4D.

\section{Introduction}

In the Law of 2003 No. 20 mandates that education is a conscious and planned effort to create an atmosphere of learning and the lecture process so that students actively develop their potential to have religious spiritual strength, self-control, personality, intelligence, noble character, and skills needed by themselves and society. Referring to the National Education System Law no. 20 of 2003, it cannot be denied that one of the conscious efforts that can be made is to develop teaching materials.

According to Panen (2019) teaching materials are materials or subject matter that are systematically arranged, which are used by teachers and students in the learning process (Prastowo, 2015). According to the Directorate of Senior High School Development (2008), the definition of teaching materials is any form of material used to assist teachers in carrying out teaching and learning activities. The material in question can be in the form of written material or unwritten material. Based on these definitions, it can be concluded that the teaching material is a learning component used by the teacher as learning material for students and helps the teacher in carrying out teaching and learning activities in the classroom. Types of Teaching Materials Types of teaching materials are divided into several grouping criteria. According to Koesnandar (2018), the types of teaching materials based on the subject consist of two types, namely: (a) teaching materials that are deliberately designed for learning, such as books, handouts, worksheets and modules; (b) teaching materials which are not designed but can be used for learning, for example clippings, newspapers, films, advertisements or news. Koesnandar also stated that when viewed from its function, the teaching materials designed consisted of three groups, namely presentation materials, reference materials, and independent study materials.

Based on the technology used, the Directorate of Senior High School Development (2008) classifies teaching materials into four categories, namely printed teaching materials, including 
handouts, books, modules, student activity sheets, brochures, leaflets, wallcharts, photos / pictures, and model / mockup. Hearing teaching materials (audio) include cassettes, radios, LPs, and audio compact disks. Audio-visual teaching materials such as video compact disks and films. According to Iis Aprinawati (2018) Some students have difficulty concentrating when doing assignments. This happens because the notes or memories are not yet organized. For that, we need a tool to help the brain think regularly in order to improve student learning outcomes so that the quality of education in Indonesia also increases. The curriculum emphasizes several aspects, namely knowledge, attitudes and skills. The broad form of the knowledge aspect includes the ability to think creatively.

In improving the quality of education in Indonesia, many efforts have been made by the government, one of which is by implementing the latest curriculum that emphasizes modern pedagogical learning in improving the standard of the learning process using a scientific approach. On the curriculum, it is emphasized on some aspects, they are: knowledge, attitude, and skills. The wider aspect of knowledge is the ability to think creatively. The ability to think creatively is something that should be possessed in learning Physics subjects which are part of Natural Sciences. Creative thinking habits can be instilled into a habit that is owned by students. In an effort to achieve creative thinking skills in students, creative and innovative teachers are also needed in planning and implementing learning.

In the learning process carried out at MAN Sebukar has been going well, the teacher has given motivation to students in increasing knowledge, attitudes, and skills by providing views on the relationship between physics material being taught with events and phenomena in everyday life, but the teacher has not using a variety of learning models and teaching materials in the learning process. This can be seen from the needs analysis conducted by researchers at MAN Sebukar so that students do not have the ability to think creatively in learning, especially in learning physics subjects. The use of physics comic learning media in the pursuit of learning process is expected to increase students' learning motivation in understanding physics concepts more easily. Because the most important aspect in creating effective learning, one of which is student motivation, when students are less interested in the lesson it will affect the way students react or pay attention to the learning given by the teacher. according to Negrete (2018) light reading has become popular reading, such as gossip tabloids, business magazines, fashion magazines, and comics.

Comics have become one of the readings favored by adolescents as well as a preferred means of communication by various groups of society by presenting interesting reading points, so that they are excellent tools used in the learning process aimed at communicating subject matter. Therefore, learning media in the form of physics comics is a source of thought for the writer because comics are not only liked by children, adolescents, and even comics are also widely liked by adults, in addition comics also have more interesting pictures and texts so that students understand the material more easily. contained in the comic which contains physics lessons.

Learning activities are directed to empower all potential students into expected competencies. Along with the explanation in Permendikbud Number 81 A of 2018, it is said that: In principle, 
learning activities are an educational process that provides opportunities for students to develop their potential into increasingly increasing abilities in the attitudes, knowledge, and skills they need to live. and for the community, nation, and contribute to the welfare of mankind. Therefore, learning activities are directed at empowering all potential students into the expected competencies (Adi W Gunawan, 2013). Complex events that are composed include elements of many songs, materials, facilities, equipment, and procedures that influence each other to achieve learning goals, which is an understanding of the teaching and learning process (Barrow, Harold M., and Mc Gee, Rosemary, 2019). Where learning and teaching are two concepts that cannot be separated from one another, when learning and teaching activities occur that is what is called the learning process (Brog and Gall, 2019).

Problem Based Learning (PBL) is a learning model that uses real-world problems as a context for students to learn about problem solving skills, as well as to acquire essential knowledge and concepts from subject matter (Erson \& Baser, 2017). According to Barell (2017), Problem Based Learning (PBL) learning model is a series of activities in the learning process that is oriented towards solving problems faced scientifically. It is a view that argues that students will compile knowledge by building reasoning from all the knowledge they have already acquired and from all that is obtained as a result of interacting with fellow students (Munandar, 2019). In order for students to have experiences as what they will face in real life, Problem Based Learning (PBL) has the idea that learning can be achieved if educational work is focused on authentic, relevant, and presented tasks or problems in a context, it provides new experiences. for students so that the learning process becomes more meaningful. This experience is very important because effective learning starts from concrete experiences.

Nurseto (2018) said that comics are a graphic form that can be used in teaching. Comics can also be a form of cartoons that reveal characters and act out a story that is closely related to the image presented without a long line of sentences. (Surjanti, 2018). Moreover, comics are visual media that have the power to convey information in a popular and easy to understand manner because comics have meaning as images and symbols that are close together, adjacent to a certain order to obtain information and provide aesthetic value (Scoot, 2018). Comics are stories that are presented and told in a sequence of images with a distinctive list and type, namely a combination of words and pictures.

If the comic that is made contains material that will be conveyed in the learning process so that the comic can be used as teaching material. Nurseto (2018) said that learning comics have a function to convey learning messages, in this context learning occurs on the communication process between learners (teachers and students) and learning sources (learning comics) so that communication will run optimally if the learning messages are conveyed clearly in sequence and interesting to be studied. In designing comics as teaching materials, one thing to pay attention to is the design of comics that attracts students 'attention and reading interest so that it can increase students' curiosity and motivation to learn the concepts presented in these comics. 
Creative thinking is the ability to use the structure of thinking to create something new which is marked by the addition of aspects of flexibility, authenticity and quantity possessed by students. Students' creative thinking skills are the level and score that can be measured. Where in increasing the ability of creative thinking skills means increasing the score of students' ability to understand problems, fluency, flexibility and novelty problem solving (Siswono, 2015). So it can be said that creative thinking skills are cognitive skills to generate and develop new ideas, new ideas as a development of previously born ideas and skills to solve problems from various points of view. Newton's Law material is one of the physics materials for senior high school students in the 2018 curriculum. The purpose of this material is demanding the students to analyze the laws related to straight motion at constant velocity and acceleration and relate them to problems in real life. In addition, in this material, the students are also required to be able to carry out simple experiments.

Based on the explanation above, the authors designed the physics comic for Senior high school students based on Problem Based Learning (PBL) to improve students' creative thinking skills on Newton's Law material. With the aim of producing valid, practical, and effective teaching materials.

\section{Method}

In this study, a product has been produced in the form of a physics comic for high school / Islamic high school learning that was valid, practical, and effective to be applied in the classroom. This research is a research and development (R \& D) as described in the formulation of the problem above. Research and development method is research method used to produce certain products (Sugiyono, 2008). Moreover, Borg and Gall (1979) stated that "Educational research and development $(\mathrm{R} \& \mathrm{D})$ is a process used to develop and validate educational products". In developing and producing a product in the form of a curriculum, modules, learning packages, text books, physics comics, evaluation tools, models, or other products that can solve problems in learning are included in development research. In development research, efforts to develop and produce in the resulting product are PBL-based high school / Islamic high school physics comics that are valid, practical, and effective.

The development of SMA / MA physics comics based on Problem Based Learning (PBL) uses the Four-D (4-D) model, which was proposed by Thiagrajan (2018). The 4-D development model consists of 4 stages, namely Defining, Designing, Developing (development), and Disseminating (deployment). In designing this comic, researchers used the four stages of the 4-D development model which in its implementation also has 4 stages in its implementation. The 4 stages of designing this research can be seen in the following figure: 


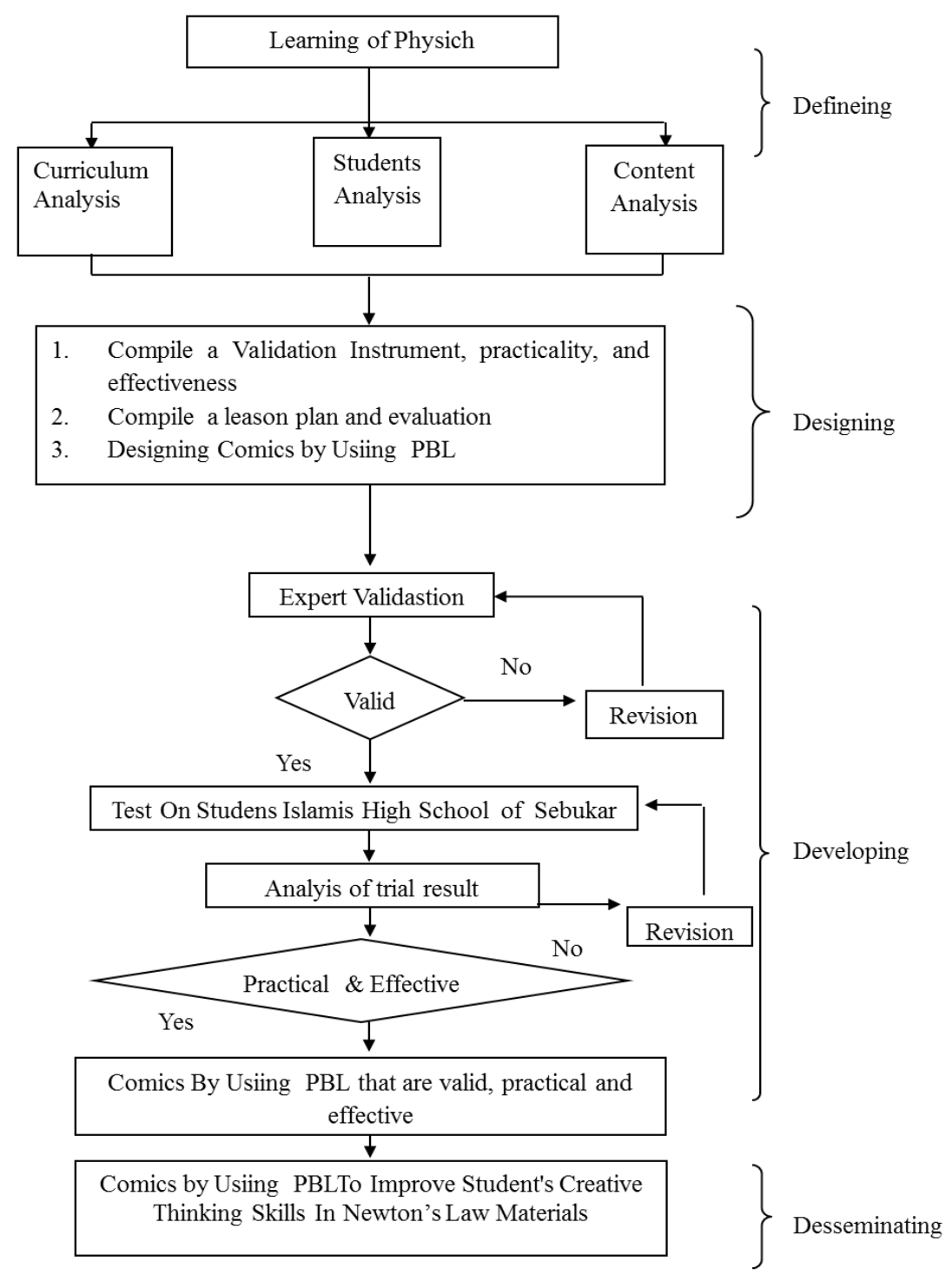

Figure 1. Steps of developing physics comics for senior high school/islamic senior high school students with PBL Based on Newton's law material

On figure 1 above, it is showed the steps conducted in designing physics comics for senior high school/islamic senior high school students with PBL Based on Newton's law material . In designing the Physics Comic by using Problem Based Learning (PBL) for high school / Islamic high school students, researchers used the 4-D model (Four D Models) in order to improve creative thinking skills on the subject of Newton's Law high school / Islamic high school. 


\section{Result and Discussion}

\section{Defining Stage}

This defining stage is the basis of the high school or Islamic high school physics comic design to improve creative thinking skills in Newton's law material used by physics teachers. If there is a mismatch between the Physics comics section and the curriculum demands, this section needs to be developed or if the teacher does not use teaching materials in the form of senior high/Islamic senior high physics comics, before the comics are designed / made, the process of the initial analysis results is carried out first.

The results of the students' need analysis showed the low acquisition of students' competencies, which is due to the low students' creative thinking skills. So that the teaching materials are needed that can improve creative thinking skills in order to foster an understanding of grade $\mathrm{X}$ on Physics material, one of this is Newton's law material and its application. For the motivation of students in learning physics, the concepts and principles of physics are taught in simple language and are associated with everyday life. In addition, students also need appropriate teaching materials and learning models to improve students' creative thinking skill. As for the motivation of students in learning physics if the concepts and principles of physics are taught in simple language and are associated with everyday life. In addition, students also need appropriate teaching materials and learning models to improve students' creative thinking skills.

\section{Designing Stage}

After the defining stage is carried out, a designing stage is carried out for the designing of senior high/Islamic senior high physics comics to improve creative thinking skills in the subject matter of Newton's Law. The early stage designing to produce a physics comic script is shown in Figure 2. After that, a Physics comic was designed which had applied a problem-based learning model and the achievement of creative thinking skills indicators, as shown in Figure 3. 


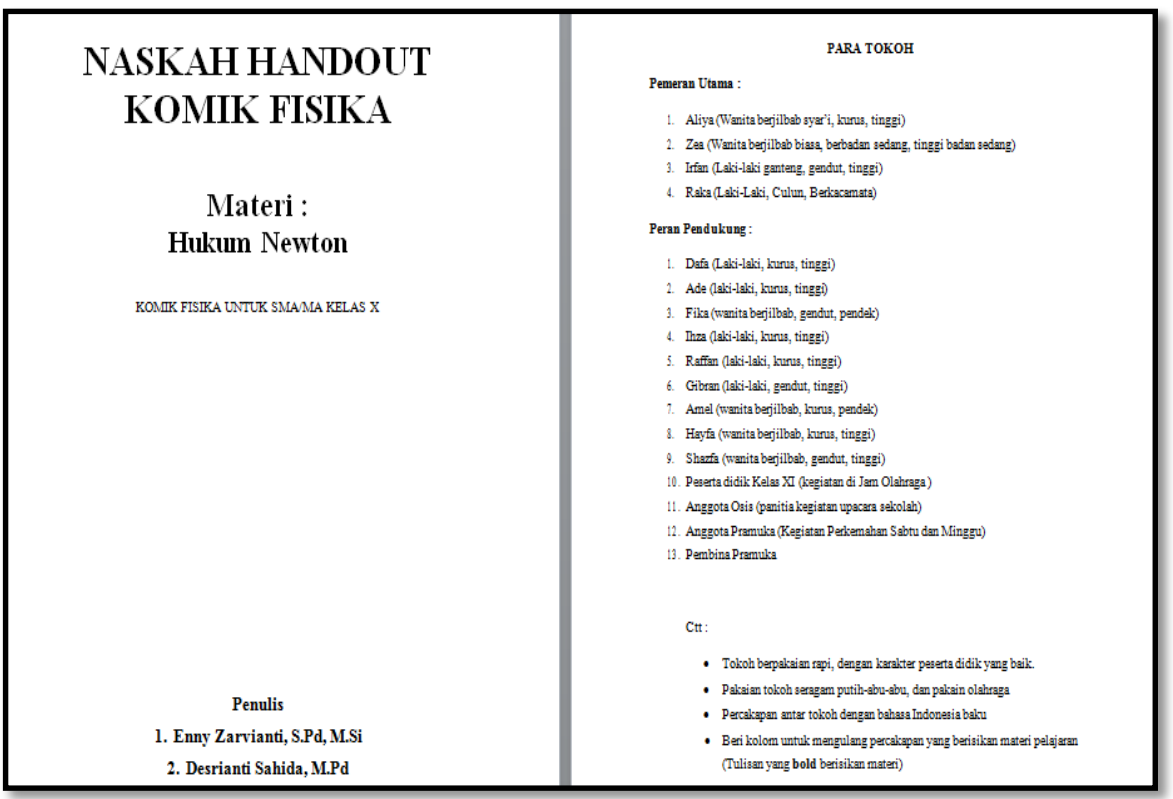

Figure 2. Physics comic script in the form of a Physics comic
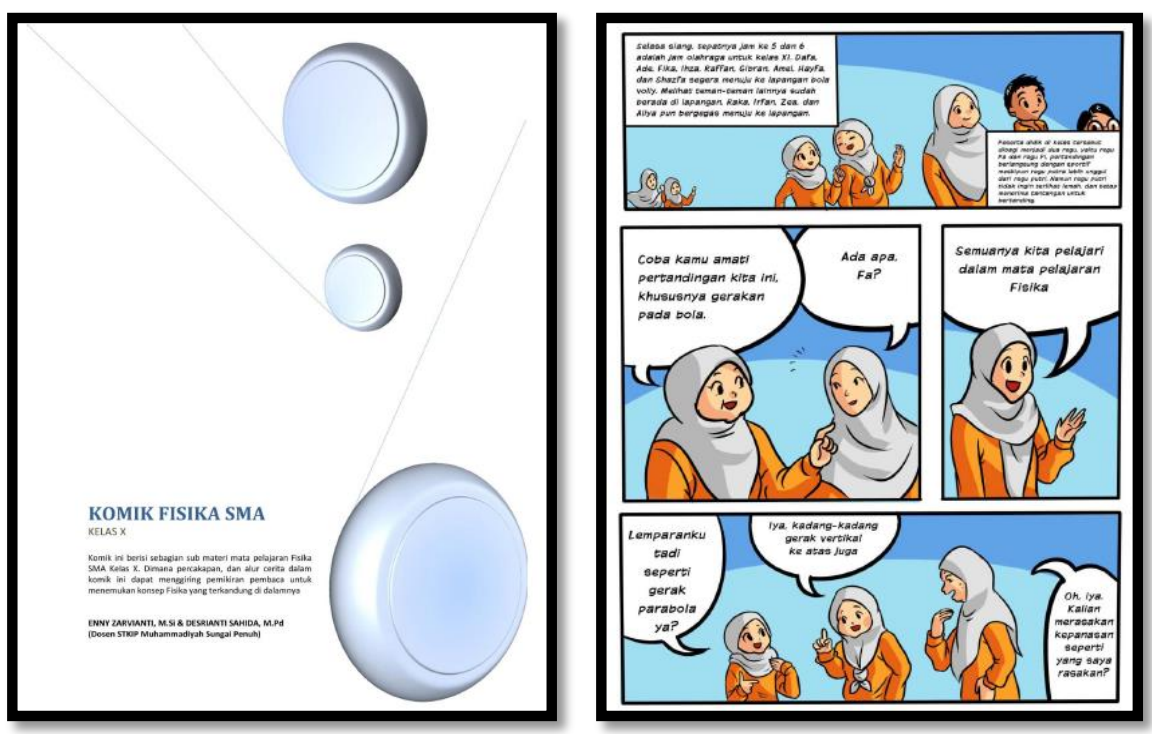

Figure 3. Design of senior high/Islamic senior high Physics Comics based on Problem Based Learning (PBL) to improve Creative Thinking Skill indicators

\section{Developing Stage}

After the defining stage and the designing stage of developing SMA / MA Physics Comics to improve creative thinking skills in Newton's Law material, then it was validated by two experts (Physics lecturers) from STKIP Muhammadiyah Sungai Penuh and one physics teacher at MAN Sebukar, Kerinci District, Jambi Province. Assessment includes content validity, construction, and language. 
Based on the validator's suggestions in Table 1, the SMA / MA Physics Comics to improve creative thinking skills in Newton's legal material were revised. Validation can be said to be complete if the validator has stated that the developed physics comic is valid. That the results of the validator's assessment indicate that everything designed is in the valid category. For the validation results can be seen in table 1.

Table 1. The Validation Results of Physics Comics for SMA / MA

\begin{tabular}{cccc}
\hline No. & Meeting & Average (\%) & Category \\
\hline 1. & Lesson Plan & 0,82 & Valid \\
2. & Physics comic & 0,85 & Valid \\
3. & Assessment & 0,88 & Valid \\
\hline & Average & 0,85 & Valid \\
\hline
\end{tabular}

Based on Table 1, it can be seen that the results of the validator's assessment show everything designed is in the valid category. Thus, SMA / MA Physics Comics which consist of lesson plans, physics comics, and assessments can be tried out in classroom learning. Practicality data of SMA / MA Physics Comics were taken from the results of observations on the implementation of lesson plans and teacher and student responses on questionnaires while participating in learning using PBLbased comic-based Physics Comics to improve creative thinking skills. In summary, the results of practicality on teacher responses can be seen in Table 2 .

Table 2. Practical Results of Teacher Responses on Questionnaire

\begin{tabular}{cccc}
\hline No. & Meeting & Average $\mathbf{( \% )}$ & Category \\
\hline 1. & $1^{\text {st }}$ & 92 & Very practical \\
2. & $2^{\text {nd }}$ & 95 & Very practical \\
3. & $3^{\text {rd }}$ & 97 & Very practical \\
\hline & Average & 94,67 & Very practical \\
\hline
\end{tabular}

The table above shows that the teacher's assessment of physics comics to improve creative thinking skills. Students who have developed have an average score of $94.67 \%$. Based on the practicality category interval, this value is in the very practical category. Physics comic is used to improve students' creative thinking skills that have been used. The questionnaire is given to 25 (twenty five) students per meeting. The results of the students' responses on questionnaire are analyzed, and it can be seen in Table 3.

Table 3. Results of Students' Responses Questionnaire Analysis

\begin{tabular}{cccc}
\hline No. & Meeting & Average $(\boldsymbol{\%})$ & Kategori \\
\hline 1. & $1^{\text {st }}$ & 91 & Very practical \\
2. & $2^{\text {nd }}$ & 92 & Very practical \\
3. & $3^{\text {rd }}$ & 95 & Very practical \\
\hline & Average & 92,67 & Very practical \\
\hline
\end{tabular}


The table above shows that the results of the analysis of the students' responses to physics comics that have been developed with an average value of $92.67 \%$ are in the very practical category. This result of the students' response questionnaire analysis is taken at seven meetings with the teacher's responses on questionnaire about practicality. The effectiveness of high school/ islamic high school Physics Comics obtained in this research is at the development stage by looking at the minimum completeness value which has a classical completeness value if $\geq 70 \%$ of students have reached the completeness score, namely with $86.29 \%$ completeness of the 25 students. The criteria for effective teaching materials are if the teaching materials have been used, there is a positive impact on students' learning outcomes. According to Sukmadinata (2005), learning outcomes in knowledge competencies can be said to be effective if they reach a predetermined completeness value. Comics that are made are said to be effective if the students' learning outcomes have reached $\geq 70 \%$ of the learning objectives that have been compiled, as the completeness score has been determined by the education unit.

In the assessment of students' knowledge, it increased to $86.26 \%$ of the total number of students who had mastered more than $70 \%$ of the learning objectives that had been set with an average score of 74.29. This shows the success of students in finding problems and solving physics problems in the developed physics comic. In addition, the PBL step has also succeeded in guiding students in mastering the material by fully involving them in the learning process.

In the assessment of students' attitudes, $80.26 \%$ of the total number of students had met the determined attitude assessment indicators. This showed that the attitude of students was in the very good category and became a habit. In respondents' observations, as far as the learning process, there are indicators of students' curiosity attitudes that are lower than other indicators of attitude because the students' high curiosity attitude cannot be seen clearly by the respondent.

In the skill assessment, $84.94 \%$ is close to $85 \%$ of the total number of students who have fulfilled the skill assessment aspects set with an average score of 84 in the very good category and based on the effectiveness test carried out, it is said that physics comics to improve creative thinking skills in Newton's Law material that has been made is already in the effective category and the average value of students' creative thinking skills is increasing at each meeting, seen from their excellence reaching the $100 \%$ position. This means that all students have reached the completeness value. This finding is in line with the increase in students' creative thinking skills.

Due to the use of high school/ Islamic high school physics comics in learning based on the PBL model, in the step of collecting and sharing information, finding solutions, determining the best solution, and presenting solutions, it can bring up indicators of flexibility, originality, and elaboration aspects. Thus, it can be said that students' creative thinking skills have been fulfilled by applying the PBL model in learning. This is in line with the opinion of Ningsih (2015) who states that one of the factors that influence the creative thinking skill indicator is the application of the PBL model. 
The potential impact for students is also supported by the existence of the PBL model. Students can solve physics problems by relating events around them in the learning process. This is in line with the opinion of Darwis (2014), which states that student learning competencies can increase with the PBL model. Apart from having a potential impact on students, this comic also had a positive impact on teachers. Teachers can overcome student learning difficulties in physics material which is dominated by material concepts and principles. Teachers can meet the availability of teaching materials that are attractive and easily understood by students and train students to be independent in solving physics problems.

\section{Disseminating/Deployment Stage}

In accordance with the objectives of this deployment stage, it is necessary to test the practicality and effectiveness if it is tested in different classes. The practicality test results at the disseminating stage are also in the very practical category. This is evidenced by the results of the students' responses on questionnaire to the use of physics comics reaching a score of $94.33 \%$ in the very practical category. Based on these results, it can be stated that the SMA / MA physics comics developed are very practical to use in different classes.

Table 4. Class Knowledge Assessment Results

\begin{tabular}{ccc}
\hline No. & Meeting & Average (\%) \\
\hline 1. & $1^{\text {st }}$ & 79 \\
2. & $2^{\text {nd }}$ & 80 \\
3. & $3^{\text {rd }}$ & 88 \\
\hline & Average & 82,33 \\
\hline
\end{tabular}

Table 4 is the results of the analysis of the effectiveness test of physics comics high school/ islamic high school at the disseminating stage. In the assessment of students' knowledge, the percentage of completeness reached $82.33 \%$. This shows the success of students in the distribution class in finding problems and solving physics problems using high school/MA physics comics. In addition, the PBL step has also succeeded in guiding students in the distribution class in mastering the material by fully involving students in the learning process.

In the attitude competition, students achieved an average score of $87.43 \%$ and it showed that the students' attitudes were in the very good category overall. However, when viewed from the results of respondents' observations, the indicators of cooperation, conscientiousness, and responsibility are higher than the indicators of curiosity and communication. This is because the two attitudes are not clearly visible to the respondents; it can be proven by the curiosity of students by communicating directly to group members and collecting information from other teaching materials. In short, authors suggest the teachers to remind students that there are indicators of attitudes that must be owned and highlighted.

In the skill competency, it reached an average score of $89.17 \%$ with the very good category, it was seen an increase in the indicators of students' tool-assembling skills. This also happened to the 
skills indicator to participate and to write conclusions, with the same treatment, resulting in an increase in these indicators to increase at the next meeting.

Based on the results of the assessment of students' knowledge, attitudes, and skills at the disseminating stage, it can be said that physics comics to improve creative thinking skills in physics class $X$ are in the effective category, with an average score of $\geq 70$ for each, within the criteria complete and successful. According to Riduwan (2008), the results of the average assessment of attitudes, skills, and knowledge can be concluded that the teaching materials developed are in the effective or ineffective category. Based on the effectiveness test that has been carried out, it can be said that physics comics to improve creative thinking skills in Newton's law material are also effectively used in different classes.

Physics comic for SMA / MA that has been made can improve students' creative thinking skills, the results of increased creative thinking skills are obtained from the results of the evaluation of the domain of knowledge processed through the gain score equation where the gain score obtained is 0.63 . The technique used to obtain the value that will be processed through the gain score equation is to do a pre-test at the beginning of the meeting and a post-test at the end of the meeting. After processing the data through the gain score equation, it can be seen clearly that there is an increase in creative thinking skills, where there is an increase in the average score of students, and the increasing score in each meeting.

The increasing score is because the use of physics comics in learning uses the PBL model, by directly involving students in analyzing and solving problems. From the first step of PBL, which is the step of finding a problem to the last step of PBL, which is the step of presenting a solution, it can improve students' ability to find problems and to find the solutions to these problems. Thus, students' creative thinking skills can be fulfilled. This is in line with the opinion of Gorghiu (2019) who states PBL is a model that uses problems from the real world, so that students can improve creative thinking skills in solving these problems. The application of the PBL model in physics comics can provide motivation for students to take part in the learning process. This can be seen from several indicators of the practicality of physics comics according to the responses of teachers and students. The potential impact for these students is supported by the existence of the PBL model. Students can solve physics problems in the learning process.

In addition to having an impact on students, physics comics to improve creative thinking skills in physics in grade $\mathrm{X}$ also have a positive impact on teachers. Teachers can overcome students' learning difficulties in physics material which is dominated by material concepts and principals, teachers can meet the availability of teaching materials that are attractive and easy to understand by students, and train students' independence to solve physics problems. 


\section{Conlusions}

The results of the blinding of SMA / MA physics comics based on the PBL comic model on Newton's Law material meet the criteria of validity, practicality, and effectiveness. The average validity test of the physics comic aided comic was 0.85 with the valid category. The average practicality test for physics comics is $94.67 \%$ in the very practical category. There was an increase in the competency scores of the knowledge, attitudes, and skills of students at each meeting, this shows that the physics comics for SMA / MA that were developed were effectively used in learning.

High school physics comics based on the PBL model in Newton's law material can be used as teaching materials in the learning process, so that the physics learning process at the senior high/Islamic senior high level can run well as it is mentioned in the indicator plan, and learning objectives, as weell as it can motivate the students to learn more in order to be knowledgeable and they will be able to see learning relationship with the aspects that exist in the environment. This research has shown that there is an increase in the creative thinking skills of students in physics learning that applies the PBL model. Learning activities based on the PBL model are able to encourage the students to build their own knowledge through problems that become a stimulus for students' curiosity during the learning process. So that it is possible to increase the competence of students in determining priorities for problem solving steps, an increase in creative thinking skills during problem solving activities takes place. PBL-based high school physics comics on Newton's law material can be used as a teaching material that supports the implementation of the learning process in accordance with the 2013 curriculum that has been applied today. The 2013 curriculum is a curriculum that emphasizes the personal experience of students through the process of observing, directly reasoning every problem so that there is an increase in students' creative thinking skills. The PBL model is very helpful in the learning.

\section{References}

Adi, W Gunawan. (2013). Genius Learning Strategy. Jakarta: Gramedia Pustaka Umum.

Barel, A. O., Paye, M., dan Maibach, H. I. (2019). Handbook of Cosmetic Science and Technology (Third Edition). Informa Healthcare USA Inc., New York.barell.

Barrow, Harold M., dan Mc Gee, Rosemary. (2019). A Practical Approach To Measurement in Phisycal Education. New York: Lea \& Fibger.

Brog Dan Gall. (2019). Educational Research: An Introduction. Jurnal New York \& London: Longman. Vol. 3 (1).

Erson, dan Baser. (2017). The Effect Of Problem Based Learning Methode In Higher Education On Creative Thinking. Jurnal Turkey: Ondakuz Mayus University. Vol. 103 (1).

Gorghiu, dkk. 2019. Problem Based Learning an Efficient Learning Strategy In The Science Lessons Context. Jurnal Romania : University Targoviste. Vol. 191, (Diakses 14 April 2020). 
Iis Aprinawati. (2018). Penggunaan Model Peta Pikiran (Mind Mapping) untuk Meningkatkan Pemahaman Membaca Wacana Siswa Sekolah Dasar. Jurnal Basicedu. Vol 2(1) hal. 140-147.

Kemendikbud. (2018). Lampiran Permendikbud Nomor 81A Tahun 2018 Tentang Implementasi Kurikulum Pedoman Umum Pembelajaran. Jakarta: Kementerian Pendidikan dan Kebudayaan RI.

Koesnandar. (2018). Pengembangan Bahan Ajar Berbasis Web. [Online] tersedia di http://www.teknologipendidikan.net diakses tanggal 05 Januari 2020.

McCloud, Scoot. (2018). Memahami Komik. Jakarta: KPG.

Munandar. (2019). Mengembangkan Bakat Dan Kreativitas Anak Sekolah. Jakarta: PT. Gramedia.

Negrete. (2018). Contraction a Comic to Communicate Scientific Information About Sustainable Development and Natural Resources In Mexico. Jurnal Mexico : UNAM. Vol. 103, (Diakses 14 April 2020).

Ningsih. (2019). Komparasi Kemampuan Berpikir Kreatif Matematis Siswa Menggunakan Pembelajaran Matematika Humanistik Dan Problem Based Learning dalam Setting model Pelatihan Innomatts. Semarang: Universitas Negeri Semarang.

Nurseto, Tejo. (2018). Membuat Media Pembelajaran yang Baik. Jurnal Ekonomi \& Pendidikan. Volume 8 (1) : halaman 19-35.

Pannen, Paulina, dkk. (2019). Kontruktivisme dalam Pembelajaran. Jakarta: Depdiknas.

Prastowo, Andi. (2015). Metode Penelitian Kualitatif dalam Perspektif Rancangan Penelitian. Jogjakarta: Ar-Ruzz Media.

Siswono, T. Y. E. (2015). Upaya meningkatkan kemampuan berpikir kreatif siswa melalui pengajuan masalah. Jurnal Pendidikan Matematika dan Sains. Jurnal Pendidikan Matematika dan Sains. FMIPA Universitas Negeri Yogyakarta. Tahun X, No. 1, Juni 2005. ISSN 1410-1866, hal 1-9.

Sugiyono. (2018). Metode Penelitian Kuantitatif, Kualitatif, dan R\&D. Bandung: Alfabeta.

Thiagrajan. (2018). Instructional Development For Training Teachers Of Exceptional Children. Indiana: Indiana University Bloomington. 